\title{
PENGALAMAN BELAJAR MAHASISWA KEDOKTERAN DALAM PENGGUNAAN REKAMAN KULIAH SEBAGAI MEDIA PEMBELAJARAN
}

\author{
Lukman Hakim ${ }^{1 *}$, Fundhy Sinar Ikrar Prihatanto ${ }^{2}$, Musofa Rusli ${ }^{3}$ \\ ${ }^{1}$ Fakultas Kedokteran, Universitas Airlangga, Surabaya - INDONESIA \\ ${ }^{2}$ Departemen Medical Education, Research, and Staff Development Unit, Fakultas Kedokteran Universitas Airlangga, \\ Surabaya - INDONESIA \\ ${ }^{3}$ Departemen Ilmu Penyakit Dalam, Fakultas Kedokteran Universitas Airlangga, RSUD Dr. Soetomo, Surabaya - INDONESIA
}

\begin{abstract}
Background: Recorded lecture is a type of learning media which the lecturers record their voices when lecturing. This type of media is popular in many universities outside Indonesia. Faculty of Medicine Universitas Airlangga is developing electronic learning using recorded lecture in 2016. This study aimed to learn the experience of college student about the usage of recorded lecture, the impact to their learning style, and their hopes about the implementation of recorded lecture in Faculty of Medicine Universitas Airlangga.
\end{abstract}

Method: This qualitative study applied content analysis design. The variable used are age, gender, intelligence quotient, learning style, learning equipment, experience when using learning media, and busyness in student affairs.

Results: Eleven subjects are interviewed. The results are variably different between the subject. There are seven themes arise from the analysis results, for instance: 1) classical class alone was not enough, need another alternative; 2) the recorded lecture was similar with the one in internet; 3) used recorded lecture just for a few times; 4) recorded lecture was very beneficial; 5) the recorded lecture was too long; 6) college students are very busy outside the class; 7) a wish for the improvement og the recorded lectures, both quality and quality.

Conclusion: The experience felt by medical education students on the use of recordings still varies. In general, students feel helped by the recording of lectures, on the other hand there are students who are not satisfied with the quality and quantity of lecture recordings provided by the campus. Massive and comprehensive improvements are needed in all aspects of providing lecture records, both in terms of teachers and in terms of technology support

Keywords: recorded lecture, content analysis, qualitative research, medical student, electronic learning.

\section{ABSTRAK}

Latar belakang: Rekaman kuliah adalah jenis dari media pembelajaran dimana pengajar merekam suaranya ketika sedang memberi kuliah. Media jenis ini sangat populer di berbagai universitas di luar Indonesia. Fakultas Kedokteran Universitas Airlangga sedang mengembangkan pembelajaran elektronik menggunakan rekaman kuliah pada tahun 2016. Penelitian ini bertujuan untuk mengkaji perspektif dari mahasiswa dalam penggunaan rekaman kuliah, dampak terhadap pola belajar, dan harapan mereka terhadap implementasi dari rekaman kuliah di Fakultas Kedokteran Universitas Airlangga.

Metode: Penelitian kualitatif ini menggunakan desain penelitian analisis isi (content analysis). Variabel yang digunakan adalah umur, jenis kelamin, kecerdasan, pola belajar, perlengkapan belajar, pengalaman belajar ketika menggunakan media pembelajaran, dan kesibukan di kegiatan kemahasiswaan.

*corresponding author, contact: lukkun.stratos@gmail.com 
Hasil: Sebelas subjek diwawancarai. Hasil dari wawancara bervariasi diantara subjek. Terdapat tujuh tema yang dapat diangkat dari hasil wawancara, yaitu: 1) pola belajar klasikal saja tidak cukup, butuh alternatif; 2) rekaman kuliah seperti tutorial di internet; 3) sesekali saja menggunakan rekaman kuliah; 4) rekaman kuliah sangat bermanfaat; 5) rekaman kuliah terlalu lama durasinya; 6) mahasiswa sekarang sangat sibuk diluar waktu perkuliahan; 7) harapan semoga rekaman kuliah diperbaiki kualitas dan kuantitasnya.

Kesimpulan: Pengalaman yang dirasakan oleh mahasiswa pendidikan dokter terhadap penggunaan rekaman masih bervariasi. Pada umumnya mahasiswa merasa terbantu dengan adanya rekaman kuliah, dilain sisi terdapat mahasiswa yang belum merasa puas terhadap kualitas dan kuantitas rekaman kuliah yang disediakan oleh kampusnya. Diperlukan perbaikan yang masif dan menyeluruh pada seluruh aspek penyediaan rekaman kuliah, baik dari sisi pengajar maupun dari sisi pendukung teknologi.

Kata kunci: rekaman kuliah, analisis isi, penelitian kualitatif, mahasiswa kedokteran, pembelajaran dalam jaringan.

\section{PENDAHULUAN}

Perkuliahan langsung masih menjadi metode utama dalam proses pendidikan dokter. ${ }^{1}$ Dalam perkuliahan langsung, mahasiswa dan dosen diharuskan berada dalam dimensi ruang dan waktu yang sama. ${ }^{1}$ Seiring berkembangnya zaman, pola perkuliahan langsung mengalami banyak evaluasi terkait aspek keterbatasan akses, biaya, ruang, dan waktu. Penggunaan teknologi dalam proses perkuliahan menjadi salah satu fitur yang menjanjikan di seluruh dunia. ${ }^{2}$ Teknologi modern yang paling banyak digunakan secara luas di dunia dalam proses perkuliahan adalah rekaman kuliah atau dalam Bahasa Inggris disebut recorded lecture. ${ }^{3}$

Rekaman kuliah mengacu pada perkuliahan yang disampaikan oleh penyaji mata kuliah, namun dalam bentuk rekaman satu arah, dari penyaji kepada pendengar. Rekaman inilah yang dapat diakses oleh mahasiswa melalui banyak variasi media. ${ }^{3}$ Beberapa studi telah membuktikan bahwa mahasiswa pendidikan dokter merasa rekaman kuliah sebagai hal yang berguna dan efektif dalam pembelajaran. ${ }^{4-8}$ Rekaman kuliah juga berdampak pada turunnya angka kehadiran mahasiswa pada kuliah langsung pada universitas yang tidak mewajibkan mahasiswanya hadir pada kuliah langsung. ${ }^{9}$ Pada tahun 2000 hingga 2009 rekaman kuliah masih sedikit digunakan oleh mahasiswa pendidikan dokter. Rekaman kuliah paling sering digunakan oleh mahasiswa yang tidak mengerti materi yang diajarkan dosen secara langsung. ${ }^{10}$ Pada tahun 2013 rekaman kuliah difungsikan oleh mahasiswa sebagai pengganti kuliah langsung maupun sebagai suplemen belajar. Rekaman kuliah berperan sebagai sumber penting untuk mahasiswa pendidikan dokter dalam mengembangkan diri secara independen (self-learner). ${ }^{9}$ Beberapa hal diatas bermakna bahwa rekaman kuliah bagi mahasiswa pendidikan dokter dapat memberikan dampak yang baik maupun buruk.

Rekaman kuliah yang digunakan dalam penelitian ini bentuk presentasi dengan suara tertanam yang bisa di pelajari oleh mahasiswa secara dalam jaringan (daring), sehingga mahasiswa dapat memiliki kebebasan untuk mempercepat, menunda, maupun mengulangi materi yang dipelajari. ${ }^{9}$ Tujuan dari penelitian ini adalah mengkaji perspektif mahasiswa pendidikan dokter dalam penggunaan rekaman kuliah di Fakultas Kedokteran Universitas Airlangga (FK UNAIR).

\section{METODE}

Penelitian ini merupakan penelitian kualitatif menggunakan data primer hasil wawancara. Data primer hasil wawancara ini kemudian dianalisis menggunakan desain penelitian analisis isi atau yang lebih dikenal dengan content analysis. ${ }^{11}$ Jumlah narasumber yang diwawancarai adalah 11 orang 
mahasiswa tahun pertama di Fakultas Kedokteran Universitas Airlangga. Jumlah ini didapatkan menggunakan teknik purposive sampling dan disesuaikan dengan jumlah sampel yang masuk dalam kategori inklusi.

Variabel dalam penelitian ini adalah umur, jenis kelamin, kecerdasan intelektual, pola belajar, perlengkapan belajar, pengalaman menggunakan media pembelajaran, dan kesibukan kegiatan kemahasiswaan.

Teknik pengumpulan data dalam penelitian ini adalah dengan menggunakan data primer, yaitu data hasil wawancara langsung dengan metode semi-structured interview. Semi-structured interview adalah desain penelitian yang berbentuk wawancara menggunakan pertanyaan terbuka. ${ }^{12}$ Wawancara lalu dikembangkan oleh peneliti menyesuaikan bagaimana sampel merespon.

Setelah mengambil data, peneliti membuat transkrip dari wawancara. Transkrip wawancara adalah hasil ketikan dari rekaman wawancara. Hasil transkrip ini dikoreksi oleh dua orang, yaitu peneliti dan satu orang lain yang tidak terlibat dalam wawancara. Hasil transkrip lalu dianalisis menggunakan desain analisis isi untuk didapatkan kode, yaitu inti dari yang disampaikan oleh narasumber. Kode yang sudah didapat lalu dikelompokkan menjadi kerangka kode, kemudian ditarik tema yang dapat menggeneralisir dan mengekspresikan secara intelektual dan emosional mengenai kerangka kode yang ada. Penelitian ini sudah dinyatakan laik etik oleh Komite Etik Penelitian Kesehatan FK UNAIR Surabaya No. 199/EC/KEPK/FKUA/2016.

\section{HASIL DAN PEMBAHASAN}

Total seluruh data yang diperoleh dari 11 narasumber dalam bentuk rekaman suara adalah sepanjang 1 jam 52 menit. Data tersebut dikonversi menjadi transkrip sebanyak 11.705 kata. Setiap transkrip yang telah diketik dilakukan penyaringan dari jawaban dan cerita narasumber menjadi sebuah inti kalimat, kemudian inti-inti kalimat yang memiliki makna yang sama dipadatkan menjadi sebuah kode.

Tabel 1 menunjukkan tabulasi 258 kode yang disampaikan oleh narasumber setelah dikelompokkan per tema. Hampir seluruh narasumber menyampaikan seluruh tema pada setiap wawancara. Hanya narasumber ARF yang tidak menyampaikan kekurangan rekaman kuliah dan narasumber SND yang tidak menyampaikan kesibukan diluar kuliah.

Tabel 1. Rekapitulasi kode hasil wawancara

\begin{tabular}{|c|c|c|c|c|c|c|c|c|c|c|c|c|c|}
\hline \multirow{2}{*}{ No } & \multirow{2}{*}{ Tema } & \multicolumn{11}{|c|}{ Jumlah Kode tiap Narasumber } & \multirow{2}{*}{ Total } \\
\hline & & ARF & AGN & DYT & SKC & $\mathrm{ECN}$ & PSP & SND & ARY & RTH & ALV & $\mathrm{CHC}$ & \\
\hline 1 & $\begin{array}{l}\text { Pola belajar klasikal } \\
\text { saja tidak cukup, butuh } \\
\text { alternatif! }\end{array}$ & 4 & 5 & 3 & 9 & 5 & 4 & 4 & 7 & 3 & 6 & 6 & 56 \\
\hline 2 & $\begin{array}{l}\text { Rekaman kuliah } \\
\text { seperti tutorial di } \\
\text { internet? }\end{array}$ & 1 & 2 & 3 & 2 & 2 & 2 & 2 & 3 & 3 & 2 & 2 & 24 \\
\hline 3 & $\begin{array}{l}\text { Sesekali saja } \\
\text { menggunakan rekaman } \\
\text { kuliah }\end{array}$ & 2 & 5 & 2 & 7 & 2 & 5 & 3 & 3 & 1 & 2 & 2 & 34 \\
\hline 4 & $\begin{array}{l}\text { Rekaman kuliah } \\
\text { sangat bermanfaat }\end{array}$ & 9 & 6 & 4 & 3 & 1 & 4 & 5 & 5 & 8 & 7 & 3 & 55 \\
\hline 5 & $\begin{array}{l}\text { Rekaman kuliah } \\
\text { terlalu lama durasinya }\end{array}$ & 0 & 4 & 1 & 3 & 5 & 6 & 1 & 5 & 1 & 3 & 4 & 33 \\
\hline
\end{tabular}




\begin{tabular}{|c|c|c|c|c|c|c|c|c|c|c|c|c|c|}
\hline \multirow{2}{*}{ No } & \multirow{2}{*}{ Tema } & \multicolumn{11}{|c|}{ Jumlah Kode tiap Narasumber } & \multirow{2}{*}{ Total } \\
\hline & & ARF & AGN & DYT & SKC & ECN & PSP & SND & ARY & RTH & ALV & $\mathrm{CHC}$ & \\
\hline 6 & $\begin{array}{l}\text { Mahasiswa sekarang } \\
\text { sangat sibuk diluar } \\
\text { waktu perkuliahan }\end{array}$ & 1 & 2 & 2 & 2 & 1 & 2 & 0 & 3 & 2 & 2 & 2 & 19 \\
\hline 7 & $\begin{array}{l}\text { Harapan semoga } \\
\text { rekaman kuliah } \\
\text { diperbaiki kualitas dan } \\
\text { kuantitasnya. }\end{array}$ & 1 & 3 & 1 & 5 & 5 & 5 & 1 & 9 & 3 & 1 & 3 & 37 \\
\hline & Total & 18 & 27 & 16 & 31 & 21 & 28 & 16 & 35 & 21 & 23 & 22 & 258 \\
\hline
\end{tabular}

Tabel 2 menunjukkan 31 kerangka kode yang didapatkan dari kode. Lalu pengelompokan kerangka kode untuk mendapatkan tema.

Tabel 2. Rekapitulasi kerangka kode dan tema

\begin{tabular}{|c|c|c|}
\hline No & Kerangka Kode & Tema \\
\hline $\begin{array}{l}1 \\
2 \\
3 \\
4 \\
5\end{array}$ & $\begin{array}{l}\text { Pola belajar adaptasi } \\
\text { Tidak bisa mencatat lengkap } \\
\text { Intensitas belajar } \\
\text { Media belajar } \\
\text { Belajar kelompok }\end{array}$ & $\begin{array}{l}\text { Pola belajar klasikal saja tidak cukup, } \\
\text { butuh alternatif! }\end{array}$ \\
\hline $\begin{array}{l}6 \\
7 \\
8 \\
9\end{array}$ & $\begin{array}{l}\text { Paham istilah } \\
\text { Tidak paham istilah } \\
\text { Paham terjemah } \\
\text { Belum mendapatkan informasi }\end{array}$ & $\begin{array}{l}\text { Rekaman kuliah seperti tutorial di } \\
\text { internet? }\end{array}$ \\
\hline $\begin{array}{l}10 \\
11 \\
12\end{array}$ & $\begin{array}{l}\text { Pernah menggunakan } \\
\text { Alat akses } \\
\text { Belum pernah menggunakan }\end{array}$ & $\begin{array}{l}\text { Sesekali saja menggunakan rekaman } \\
\text { kuliah }\end{array}$ \\
\hline $\begin{array}{l}13 \\
14 \\
15 \\
16 \\
17 \\
18 \\
19 \\
20 \\
21\end{array}$ & $\begin{array}{l}\text { Bisa dipakai untuk review } \\
\text { Melengkapi catatan } \\
\text { Tampilan rekaman kuliah } \\
\text { Lebih efektif } \\
\text { Mudah diakses } \\
\text { Bisa diulang } \\
\text { Bisa dipakai untuk preview } \\
\text { Pengganti bagi mahasiswa yang tidak mengikuti kuliah } \\
\text { Inovasi baru }\end{array}$ & Rekaman kuliah sangat bermanfaat \\
\hline $\begin{array}{l}22 \\
23 \\
24 \\
25 \\
26\end{array}$ & $\begin{array}{l}\text { Tidak mengehemat waktu } \\
\text { Tidak bisa bertanya } \\
\text { Perlu jaringan yang bagus } \\
\text { Kurang jelas } \\
\text { Masalah etik }\end{array}$ & Rekaman kuliah terlalu lama durasinya \\
\hline $\begin{array}{l}27 \\
28 \\
29\end{array}$ & $\begin{array}{l}\text { Berdampak pada proses pembelajaran } \\
\text { Kegiatan di luar kuliah } \\
\text { Tidak berdampak pada proses pembelajaran }\end{array}$ & $\begin{array}{l}\text { Mahasiswa sekarang sangat sibuk diluar } \\
\text { waktu perkuliahan }\end{array}$ \\
\hline $\begin{array}{l}30 \\
31\end{array}$ & $\begin{array}{l}\text { Rekaman kuliah diterapkan di FK UNAIR } \\
\text { Pengembangan rekaman kuliah }\end{array}$ & $\begin{array}{l}\text { Harapan semoga rekaman kuliah } \\
\text { diperbaiki kualitas dan kuantitasnya. }\end{array}$ \\
\hline
\end{tabular}


Tema 1: Pola belajar klasikal saja tidak cukup, butuh alternatif!

Mayoritas dari narasumber memiliki pola belajar yang masih adaptif. Pola belajar mereka terus berubah sejak SMA hingga sekarang. Mulai dari semester satu hingga sekarang pola belajarnya juga masih berubah. Semua narasumber menggunakan presentasi dosen untuk belajar. Presentasi ini digunakan sebagai salah satu media belajar utama karena budaya yang sudah timbul di kalangan mahasiswa FK UNAIR, bahwa soal ujian akan banyak bersumber dari presentasi perkuliahan. Narasumber juga menggunakan media pembelajaran yang berbeda-beda, diantaranya ada yang menggunakan catatan pribadi, rangkuman kakak kelas, textbook, jurnal, dan video dari internet. Intensitas belajar juga dijelaskan oleh beberapa narasumber. Mayoritas narasumber memiliki kecenderungan untuk meningkatkan intensitas belajar mereka menjelang ujian.

Narasumber ARF memberitahukan pola belajarnya di dalam kelas, bahwa dia tidak dapat mencatat dengan lengkap apa yang dikatakan dosen selama sesi perkuliahan. Hal ini berdampak pada tidak lengkapnya catatan yang dimiliki oleh mahasiswa. Presentasi/handout yang diberikan oleh dosen tidak seluruhnya dapat melengkapi catatan mahasiswa, karena dosen seringkali mengembangkan penjelasan di ruang kuliah sesuai dengan kondisi perkuliahan. Fenomena ini dapat dilihat juga pada presentasi yang banyak menggunakan media berupa gambar/grafik, media tersebut umumnya dijelaskan secara lisan oleh dosen.

Sebagian narasumber menyampaikan bahwa mereka lebih suka belajar secara kelompok. Alasan yang dikemukakan diantaranya ketika belajar kelompok lebih mudah bertanya kepada anggota kelompok belajar. Lalu kelompok belajar bisa diajak bersamasama mengerjakan dan membahas soal-soal latihan. Sebagian besar narasumber tidak memberitahukan mengenai preferensi mereka untuk belajar secara individu ataupun kelompok, tetapi sebagian narasumber dapat di kategorikan sebagai mahasiswa yang suka belajar secara individu berdasarkan pola belajar yang digunakan, seperti belajar bersama orang tua pada yang dikemukakan subjek SKC.
Tema ini sesuai dengan penelitian dari Huggins ${ }^{13}$ bahwa tidak ada satu metode pengajaran yang paling efektif, melainkan metode metode ini saling melengkapi satu dengan yang lain. $\mathrm{Hu}^{14}$ dalam penelitiannya menyatakan bahwa metode kuliah kelas terbalik (flipped classrooms) lebih efektif dibandingkan metode kuliah klasikal. Bates dalam bukunya Teaching in a Digital Age memberikan pernyataan yaitu:

"the use of these tools or approaches should be driven by a holistic look at the needs of all students, the needs of the subject area, and the learning goals relevant to a digital age, and not by an erroneous view of what a particular generation of students are demanding." (p.267).

Kutipan ini bermakna bahwa penggunaan metode pengajaran ini harus memperhatikan kebutuhan siswa secara holistik, tidak hanya yang diinginkan oleh oleh siswa berdasarkan generasi tertentu.

\section{Tema 2: Rekaman kuliah seperti tutorial di internet?}

Seluruh narasumber memahami arti dari rekaman kuliah secara harfiah, namun sebagian besar diantaranya tidak paham istilah tersebut jika dikaitkan dengan program institusional di UNAIR. Sebagian besar narasumber mengaitkan rekaman kuliah dengan video pembelajaran yang beredar di internet, seperti yang disampaikan oleh narasumber DYT sebagai berikut:

“... menurut saya kayak apa ya, hm lecture-lecture kayak di, apa namanya, academica, pokoknya yang lecture sudah di record, habis itu di schedule kapan belajarnya, terus jadinya belajarnya dari situ."

Media yang disebut oleh narasumber mengenai rekaman kuliah bervariasi, yaitu rekaman suara, video, presentasi dilengkapi suara, dan presentasi dengan video. 


\section{Tema 3: Sesekali saja menggunakan rekaman kuliah}

Rekaman kuliah pernah digunakan oleh semua narasumber, diakses melalui laptop, hp, maupun tablet, namun penggunaan media rekaman kuliah sebagai salah satu media pembelajaran mahasiswa masih sangat rendah digunakan secara rutin, seperti yang disampaikan oleh narasumber $\mathrm{CHC}$ sebagai berikut:

“... sering dipakai sebenarnya ga sering terpakai sih, karena kalau aku sendiri orangnya itu tipenya visual jadi kalau misalnya kayak denger itu kurang nangkep, jadi lebih ke handout PPT"

Hanya sebagian kecil narasumber yang menggunakan rekaman kuliah sebagai bahan acuan belajar sampingan, sisanya hanya menggunakan rekaman kuliah sebagai bentuk antusiasme mereka terhadap teknologi dan media baru dalam pembelajaran.

\section{Tema 4: Rekaman kuliah sangat bermanfaat}

Kelebihan rekaman kuliah yang diungkapkan oleh narasumber adalah bisa dipakai untuk review materi kuliah, melengkapi catatan perkuliahan, tampilan rekaman kuliah yang atraktif, lebih efektif untuk belajar, mudah diakses, bisa diulang penggunaannya berkali-kali, bisa dipakai untuk mempersiapkan perkuliahan selanjutnya, pengganti bagi mahasiswa yang tidak mengikuti kuliah, dan inovasi baru.

Rekaman kuliah sangat membantu narasumber untuk belajar materi yang telah dikuliahkan sekaligus untuk melengkapi catatan yang belum lengkap. Catatan yang dilengkapi ini merupakan salah satu sumber utama pembelajaran dari mahasiswa, seperti yang diungkapkan oleh subjek ARF, PSP, CHC, SKC, dan ARY.

Kemampuan rekaman kuliah untuk dapat diulang dirasakan oleh narasumber sebagai salah satu keuntungan terbesar yang dimiliki oleh rekaman kuliah jika dibandingkan dengan perkuliahan tatap muka. Dengan adanya rekaman kuliah, mahasiswa bisa mengulang-ulang rekaman, terutama pada bagian yang belum dipahami oleh mahasiswa. Kemudahan akses menjadi sangat penting bagi mahasiswa, seperti yang disampaikan oleh narasumber SKC, yaitu:

“... kita yang, ketika mungkin terbatas, batasanbatasan waktu yang dimiliki saat kuliah klasik atau kuliah tidak direkam, bisa diputuskan disitu karena kita punya fitur untuk membalikkan waktu, atau playback."

Kelebihan dari rekaman kuliah telah diteliti oleh Preston $^{2}$, dimulai dari mengatasi masalah jumlah siswa yang terlalu besar, dapat diakses oleh siswa yang tidak dapat hadir di kelas, dapat diakses oleh siswa yang menginginkan fleksibilitas, dan dapat dimanfaatkan oleh siswa yang bahasa aslinya tidak sama dengan bahasa perkuliahan. Reece ${ }^{15}$ dalam penelitiannya di University of Manchester menyebutkan bahwa terdapat peningkatan nilai ujian yang bermakna pada satu mata kuliah yang menggunakan rekaman kuliah dibandingkan tahun sebelumnya yang hanya menggunakan kuliah klasik.

\section{Tema 5: Rekaman kuliah terlalu lama durasinya}

Pendapat narasumber tentang kekurangan dari penggunaan rekaman kuliah beragam. Diantaranya penggunaan rekaman kuliah tidak menghemat waktu, tidak bisa bertanya, perlu jaringan yang bagus, kurang jelas, dan masalah etik.

Penghematan waktu menjadi aspek yang dikeluhkan narasumber karena kurikulum yang digunakan di FK UNAIR sekarang terasa sangat padat, sehingga efisiensi waktu menjadi kendala pada penggunaan rekaman kuliah yang berupa rekaman penuh dari satu sesi kuliah. Solusi dari efisiensi waktu ini disampaikan melalui harapan beberapa narasumber, diantaranya mengenai pembuatan rekaman kuliah yang terpisah dari proses perkuliahan, sehingga dosen bisa membuat rekaman kuliah khusus untuk dibagikan kepada mahasiswa, tanpa ada gangguan yang dapat terjadi di dalam ruang kuliah. Jenis rekaman kuliah yang diinginkan mahasiswa juga berupa rekaman singkat, berdurasi sekitar 10 15 menit. Pendapat ini sesuai dengan penelitian oleh Thomson, Bridgstock, dan Willems ${ }^{16}$ yang menyatakan bahwa prinsip yang baik dalam video 
edukasi adalah menjelaskan tujuan pembelajaran dengan singkat, menceritakan pelajaran dengan baik, ceritakan dalam durasi sesingkat mungkin.

Pertanyaan yang muncul ketika sedang menggunakan rekaman kuliah tidak bisa ditanyakan secara langsung oleh mahasiswa. Mahasiswa harus menunggu untuk menemui dosen tersebut baru ditanyakan.

Masalah etik yang muncul pada subjek ECN berkaitan dengan pengambilan video dari kadaver. ECN berharap pihak Fakultas dapat menyediakan rekaman kuliah mengenai praktikum Anatomi, sehingga masalah etik tersebut dapat diselesaikan oleh pihak Fakultas.

\section{Tema 6: Mahasiswa sekarang sangat sibuk diluar waktu perkuliahan}

Kesibukan mahasiswa di luar perkuliahan tercermin di semua narasumber. Semua narasumber memiliki kesibukan di luar kuliah, teutama pada kegiatan ospek untuk mahasiswa baru. Sebagian besar narasumber juga mengikuti organisasi internal kampus. Kesibukan-kesibukan tersebut sebagian besar berdampak pada kelancaran pembelajaran dari narasumber, seperti yang disebutkan oleh narasumber ARY:

"...Menurut saya ada pengaruhnya meskipun tidak terlalu membuat saya terlalu berat, bisa dibilang berat tapi tidak sangat berat, seperti itu. "

Hanya satu narasumber (PSP) yang mengatakan bahwa kesibukan yang dia jalani tidak berdampak pada kelancaran pembelajaran. Kesibukan mahasiswa di luar perkuliahan merupakan hal yang umum terjadi, Caesari dan Listiara ${ }^{17}$ menyebutkan bahwa mahasiswa yang sibuk dalam aktivitas di luar perkuliahan memiliki tendensi untuk membolos kuliah dan kesulitan dalam memahami pelajaran perkuliahan.

\section{Tema 7: Harapan semoga rekaman kuliah diperbaiki kualitas dan kuantitasnya.}

Berbagai harapan tentang implementasi rekaman kuliah di FK UNAIR disampaikan oleh narasumber.
Semua harapan yang disampaikan narasumber merupakan solusi dari setiap kekurangan yang narasumber tersebut sampaikan. Harapan yang disampaikan narasumber terbagi menjadi dua golongan, yang pertama adalah harapan diterapkannya rekaman kuliah di FK UNAIR, yang kedua adalah harapan mengenai pengembanganpengembangan konsep dari rekaman kuliah yang akan diterapkan di FK UNAIR.

Pengembangan dari rekaman kuliah yang akan diterapkan di FK UNAIR yang pertama adalah pemendekan durasi. Sebagian besar narasumber mengatakan bahwa durasi yang lebih pendek lebih diminati dibandingkan durasi panjang pada rekaman kuliah penuh. Untuk mempersingkat durasi, perekaman rekaman kuliah bisa dibagi per topik bahasan dalam satu mata kuliah.

Pengembangan dari rekaman kuliah yang akan diterapkan di FK UNAIR yang kedua adalah ketersediaan materi yang lengkap dan menyeluruh untuk semua mata kuliah. Sebagian besar narasumber berharap tersedianya seluruh cakupan materi perkuliahan dalam bentuk rekaman kuliah. Dampaknya adalah mahasiswa dapat mencari rujukan pertama untuk belajar melalui rekaman kuliah yang dimiliki oleh kampus sendiri, yang akan meningkatkan minat belajar mahasiswa secara fleksibel. ${ }^{18}$

Pengembangan dari rekaman kuliah yang akan diterapkan di FK UNAIR yang ketiga adalah kemudahan akses oleh mahasiswa. Sebagian narasumber berharap mahasiswa dapat mengakses rekaman kuliah dengan mudah, tanpa ada batasan waktu, dan lintas semester, sehingga kapanpun dan dimanapun mahasiswa ingin mempelajari suatu topik, bisa digunakan rekaman kuliah sebagai media pembelajaran yang praktis dan efektif, seperti yang diucapkan oleh narasumber ARY sebagai berikut

"Karena menurut saya rekaman kuliah ini adalah sebuah media yang baik untuk mahasiswa supaya dapat belajar, mungkin kedepannya harapannya media seperti ini dapat dikemas dengan baik dalam artian disediakan dengan banyak topik, misalnya satu topik perkuliahan itu ada media seperti ini, yang pertama, manfaatnya apa? Ketika mahasiswa 
itu ingin mengakses tentang topik tersebut secara langsung, kita bisa mengaksesnya. Tanpa ada batasan waktu, seperti itu ..."

Berdasarkan uraian diatas diperlukan usaha lebih baik dari pihak pembuat konten rekaman kuliah maupun dari pihak penyedia teknologi. Pihak pengajar perlu mempelajari dasar-dasar dalam membuat rekaman kuliah yang baik, sehingga apa yang diajarkan dapat memiliki efek didaktik yang baik. ${ }^{19}$

\section{KESIMPULAN}

Kesimpulan yang diperoleh dari penelitian tentang pengalaman belajar mahasiswa dalam penggunaan rekaman kuliah adalah pengalaman yang dirasakan oleh mahasiswa pendidikan dokter terhadap penggunaan rekaman masih bervariasi. Pada umumnya mahasiswa merasa terbantu dengan adanya rekaman kuliah, dilain sisi terdapat mahasiswa yang belum merasa puas terhadap kualitas dan kuantitas rekaman kuliah yang disediakan oleh kampusnya. Diperlukan perbaikan yang masif dan menyeluruh pada seluruh aspek penyediaan rekaman kuliah, baik dari sisi pengajar maupun dari sisi pendukung teknologi.

\section{SARAN}

Perlu dilakukan penelitian kuantitatif dan kualitatif terutama di negara Indonesia setelah media pembelajaran rekaman kuliah sudah berjalan dengan baik untuk meneliti pengaruh penggunaan rekaman kuliah terhadap aspek lain seperti nilai, pemahaman, dan tingkat kehadiran kuliah. Responden yang digunakan juga perlu diperluas, tidak hanya mahasiswa namun juga pengisi rekaman kuliah, yaitu para dosen.

\section{DEKLARASI KEPENTINGAN}

Penulis menyatakan bahwa manuskrip dan penelitian ini tidak memiliki konflik kepentingan apapun.

\section{DAFTAR PUSTAKA}

1. Dooley-Hash S. Educating Physicians: A Call for Reform of Medical School and Residency. JAMA:
The Journal of the American Medical Association. 2010;304(11):1240.

2. Preston G, Phillips R, Gosper M, McNeill M, Woo K, Green D. Web-based lecture technologies: Highlighting the changing nature of teaching and learning. Australasian Journal of Educational Technology. 2010;26(6).

3. Taplin RH, Kerr R, Brown AM. Opportunity costs associated with the provision of student services: A case study of web-based lecture technology. Higher Education. 2014;68(1):15-28.

4. Cardall S, Krupat E, Ulrich M. Live lecture versus video-recorded lecture: are students voting with their feet? Academic Medicine. 2008;83(12):11748.

5. Pilarski PP, Johnstone DA, Pettepher CC, Osheroff N. From music to macromolecules: using rich media/podcast lecture recordings to enhance the preclinical educational experience. Medical teacher. 2008;30(6):630-2.

6. Lovell K, Plantegenest G. Student utilization of digital versions of classroom lectures. American Science Educator. 2009;19(1):20-5.

7. Evans DJR. Using embryology screencasts: A useful addition to the student learning experience? Anatomical Sciences Education. 2011;4(2):57-63.

8. Franklin D, Gibson JW, Samuel JC, Teeter WA, Clarkson CW. Use of Lecture Recordings in Medical Education. Medical Science Educator. 2011;21(1):21-8.

9. Gupta A, Saks NS. Exploring medical student decisions regarding attending live lectures and using recorded lectures. Medical Teacher. 2013;35(9):767-71.

10. McNulty JA, Sonntag B, Sinacore JM. Evaluation of computer-aided instruction in a gross anatomy course: A six-year study. Anatomical Sciences Education. 2009;2(1):2-8.

11. Erlingsson C, Brysiewicz P. A hands-on guide to doing content analysis. African Journal of Emergency Medicine. 2017;7(3):93-9.

12. Britten N. Qualitative Research: Qualitative interviews in medical research. British Medical Journal. 1995;311:251-3.

13. Huggins C, Stamatel J. An Exploratory Study Comparing the Effectiveness of Lecturing versus Team-based Learning. Teaching Sociology. 2015;43(3):227-35.

14. Hu R, Gao H, Ye Y, Ni Z, Jiang N, Jiang X. Effectiveness of flipped classrooms in Chinese baccalaureate nursing education: A meta-analysis of 
randomized controlled trials. International Journal of Nursing Studies. 2018;79:94-103.

15. Reece RJ. Lecture capture at the university of Manchester. Manchester; 2013.

16. Thomson A, Bridgstock R, Willems C. "Teachers flipping out" beyond the online lecture, Maximizing the educational potential of video. Journal of Learning Design, 2014;7(3).

17. Caesari Y, Listiara A. "Kuliah Versus Organisasi" Studi Kasus Mengenai Strategi Belajar Pada
Mahasiswa Yang Aktif Dalam Organisasi Mahasiswa Pecinta Alam Universitas Diponegoro. Jurnal Psikologi. 2015;12(2):164-75.

18. Bates AW. Teaching in a digital age; Guidelines for designing teaching and learning for a digital age. 2015.

19. Germany L. Beyond lecture capture: What teaching staff want from web-based lecture technologies. Australasian Journal of Educational Technology. 2012;28(7):1208-20. 